\title{
Characterising and modelling groundwater discharge in an agricultural wetland on the French Atlantic coast
}

\author{
Ph. Weng ${ }^{1}$, F. Giraud ${ }^{1}$, P. Fleury ${ }^{1}$ and C. Chevallier ${ }^{2}$ \\ ${ }^{1}$ Bureau de Recherches Géologiques et Minières, Service EAU/RMD, 1039 rue de Pinville, 34000 Montpellier, France \\ ${ }^{2}$ INRA-SAD, 545, rue Bois Maché,17450 Saint-Laurent-de-la-Prée, France \\ E-mail for corresponding author: p.weng@brgm.fr
}

\begin{abstract}
Interaction between a wetland and its surrounding aquifer was studied in the Rochefort agricultural marsh $\left(150 \mathrm{~km}^{2}\right)$. Groundwater discharge in the marsh was measured with a network of nested piezometers. Hydrological modelling of the wetland showed that a water volume of $770,000 \mathrm{~m}^{3} \mathrm{yr}^{-1}$ is discharging into the marsh, but that this water flux essentially takes place along the lateral borders of the wetland. However, this natural discharge volume represents only $20 \%$ of the artificial freshwater injected each year into the wetland to maintain the water level close to the soil surface. Understanding and quantifying the groundwater component in wetland hydrology is crucial for wetland management and conservation.
\end{abstract}

Keywords: wetland, hydrology, groundwater, modelling, marsh

\section{Introduction}

Groundwater is one of the most important components of wetland hydrology, both for quantitative and qualitative purposes, but probably is also one of the most difficult to quantify (Carter, 1986; LaBaugh, 1986). Groundwater can be the dominant component of the water budget of a wetland (Hunt et al., 1996; Cey et al., 1998; Winter, 1999; Bendjoudi et al., 2002) or only a small part of it (Brinson, 1993; Mitsch and Gosselink, 1993; Gilman, 1994; Fustec and Lefeuvre, 2000) but, whatever its quantitative contribution, groundwater input is important for the physical and chemical quality of wetlands (Hill, 1990; Devito and Dillon, 1993; Hayashi and Rosenberry, 2002).

Although groundwater behaviour is considered to be less variable than that of other hydrological systems (Hunt et al., 1997), it may be difficult to collect all the data necessary for the calculation of groundwater inflow to and outflow from wetlands (hydraulic gradients, 3D geometry of the wetland and its surroundings, hydraulic conductivity of the soil). Combining field studies and hydrological modelling generally helps to test hypotheses about the functioning of a wetland as well as quantifying the importance of groundwater in the ecosystem (Hunt et al., 1996; Tchamen and Kahawita, 1998; Morrison et al., 1999; Gasca-Tucker and Acreman, 2000; Su et al., 2000; Weng, 2000). Improving the understanding of how wetlands function and describing and quantifying their buffer role (during floods or in nitrate retention and elimination for example), will help authorities to manage such ecosystems in a sustainabledevelopment manner.

Presented here are the results of a study on the Atlantic coast of France of Rochefort Marsh, which is subject to increasing agricultural pressure and needs rules for its freshwater management. This paper demonstrates the possible water circulation in the marsh as well as its relationship with the underlying aquifer. A first approach to groundwater modelling is also presented here.

\section{Location of the study site and climatic context}

Rochefort Marsh, about $140 \mathrm{~km}$ north of Bordeaux, covers a surface area of $150 \mathrm{~km}^{2}$ extending $24 \mathrm{~km}$ east-west and $5 \mathrm{~km}$ north-south. The marsh is bounded to the west by the Atlantic Ocean and to the south by the Charente River (Fig. 1). The topography is relatively flat, about 3 metres 


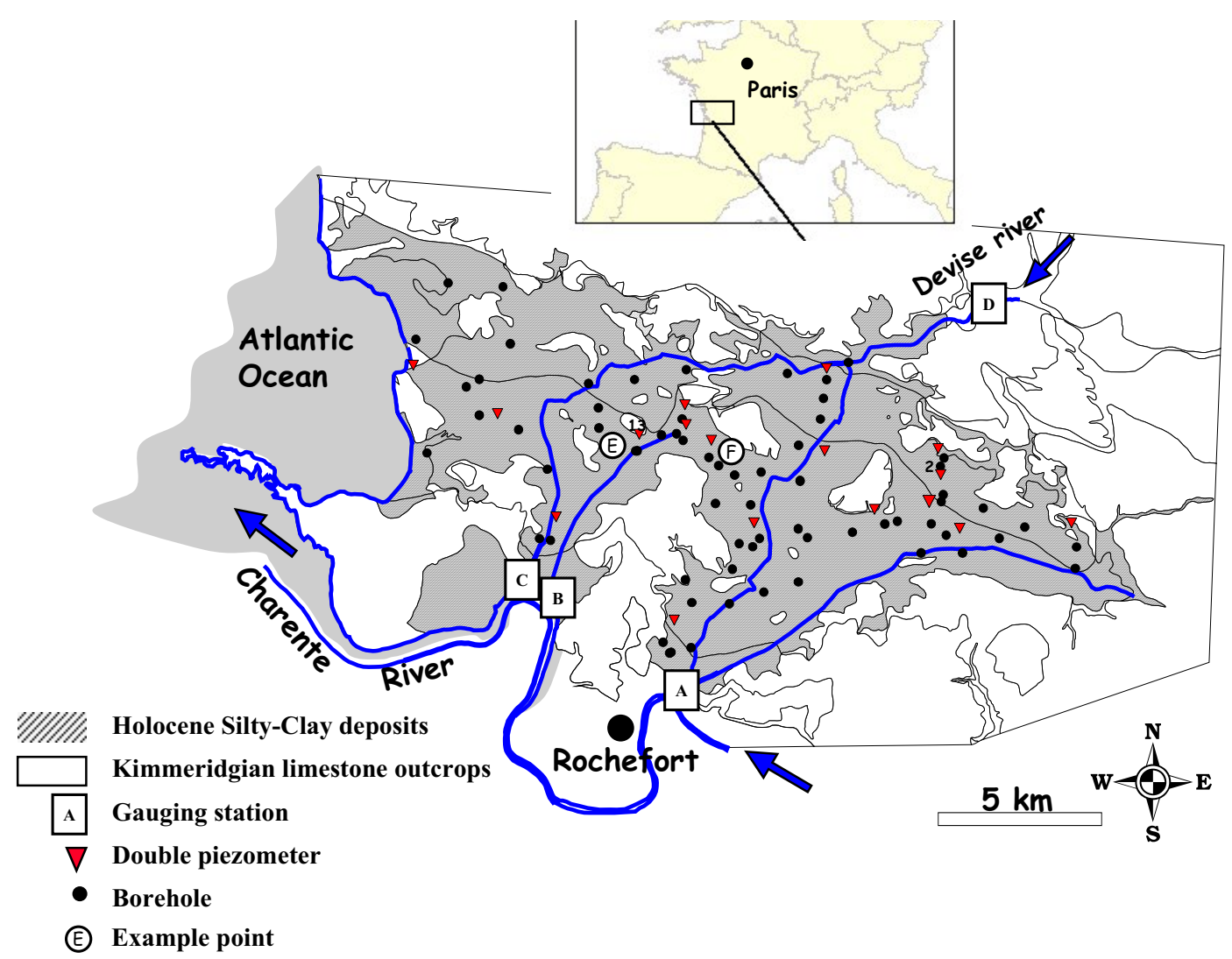

Fig. 1. Location of Rochefort Marsh and field installations.

above sea level (m.a.s.l.), with a few isolated small hills rising to about 30 m.a.s.l.

The climate around Rochefort is coastal-oceanic with a mean annual rainfall of $780 \mathrm{~mm}$ distributed irregularly throughout the year; for example, $52 \%$ of rainfall occurs between October and January (Giraud et al., 2000). Mean annual potential evapotranspiration is $783 \mathrm{~mm}, 50 \%$ of it occurring between June and August. Rainfall and evapotranspiration data were collected on site as shown in Fig. 1. During winter, the water table in the marsh is quite close below the soil surface and the marsh is commonly flooded both by surface water and by direct rainfall.

Rochefort Marsh is essentially dedicated to agriculture, comprising pasture ( $64 \%$ of the marsh surface), wheat (19\%), maize (14\%) and sunflower (3\%) crops. Agricultural pressure and highly contrasted climatic conditions between winter and summer have led all economic actors of the marsh to organize its freshwater management. For more than four centuries, different associations of farmers have managed the network of hydraulic structures in the marsh.

The Devise River drains a catchment of $150 \mathrm{~km}^{2}$ and represents most of the natural surface inflow into the marsh. Four main canals cross the marsh roughly from east to west, discharging into the Charente River through wooden sluice gates (Fig. 1: points A, B and C). A 1500-km-long network of 2-metre wide ditches, connected to those four canals, drains the marsh by gravity during high-water periods.

The water level in the Charente River has a tidal component, and the wooden gates are closed automatically when the tide is rising to avoid the influx of salt water into the marsh. In the summer also the wooden gates are closed and freshwater is pumped from the Charente River into the main canals to maintain a water level close to the soil surface, thus sub-irrigating the agricultural plots. The volume of water injected is about 3 to $4 \mathrm{Mm}^{3}$ during the summer but varies with water conditions. Except for the volume of water pumped from the Charente River, no quantitative management of freshwater in the marsh is undertaken and 
the operation of small locks, weirs, or other hydraulic structures is based on qualitative information.

\section{Geological and hydrogeological setting}

The marsh consists of Holocene silty-clay deposits and constitutes a phreatic aquifer. In view of the low permeability of the marsh sediments, it is assumed to have no connection with its surroundings. Until this study, the thickness of the marsh was not well known, but was assumed to be about 5 to $10 \mathrm{~m}$ and to be relatively homogeneous. The substratum of the marsh is a Kimmeridgian limestone, which also constitutes an aquifer that is exploited for agriculture, especially in the hills where water is used for irrigation. This Kimmeridgian limestone is exposed around the marsh and also locally in the marsh, where it forms small hillocks the highest of which is 30 m.a.s.l.

\section{Field installations}

A total of 70 exploration boreholes was drilled in the marsh down to the Kimmeridgian substratum to measure the thickness of the silty-clay deposits. In each $180 \mathrm{~mm}$ diameter borehole, different geological facies were identified in the marsh deposits and their thicknesses were determined; they vary from zero to $30 \mathrm{~m}$ thick.

Seventeen nested piezometers were installed in the marsh, each corresponding to a well drilled into the limestone with two casings with bottom screens: one down to the boundary between the marsh and the calcareous substratum, and the other intersecting the marsh and penetrating the calcareous aquifer 5 to $30 \mathrm{~m}$. These separate casings provided separate measurements of hydraulic heads in both aquifer formations. Each piezometer well was equipped with a pressure transducer and measurements were logged hourly.

The surface water flow was calculated at each wooden sluice gate acting as a surface outlet of the marsh, as well as at the surface inlet into the marsh on the Devise River (point D on Fig. 1). Hourly water-level measurements were made both upstream and downstream of the gates which present a 2-metre wide rectangular section. Water flow was then calculated using different hydraulic formulae (Lencastre, 1983). Manual gauging of the surface water flow validated the accuracy of this method.

All data were collected between 1998 and 2000 though several of the automatic devices were damaged during December 1999. Results presented in this paper therefore concern the hydrological period between September 1998 and August 1999.

\section{Results}

\section{SURFACE WATER FLOW}

During the hydrological year 1998-1999, total surface inflow from the Devise River was $32 \mathrm{Mm}^{3}$. Total outflow from the marsh into the Charente River was $72.2 \mathrm{Mm}^{3}$, distributed as follows: $22.3 \mathrm{Mm}^{3}$ for point $\mathrm{A}, 14.3 \mathrm{Mm}^{3}$ for point $\mathrm{B}$ and $35.6 \mathrm{Mm}^{3}$ for point $\mathrm{C}$ (Fig. 2). High flow occurred essentially between January and March, corresponding to a period of major rainfall on the marsh. During this period, $70 \%$ of the annual surface water flowed out of the marsh.

Based on the monitoring of the surface water level, the difference between surface inflow and surface outflow from the marsh was calculated as $40.2 \mathrm{Mm}^{3}$ during the hydrological year 1998-1999. This corresponds to the volume of effective rainfall on the marsh itself $\left(150 \mathrm{~km}^{2}\right.$ surface area) and that of its catchment represented by the Kimmeridgian outcrops ( $108 \mathrm{~km}^{2}$ surface area).

Between June and September, gates were shut and no water flowed out of the marsh. A total volume of $4 \mathrm{Mm}^{3}$ of freshwater was injected continuously from the Charente River into the marsh to maintain water level in the canals close to the surface. Some field experiments made on different parcels showed that the water level in the ditches is well connected to the groundwater table in the marsh, both in winter where the water level in the ditches is lower than the groundwater table and in summer where the surface water level is higher than the groundwater table (Gilbert, 1998; Fleury, 2001).
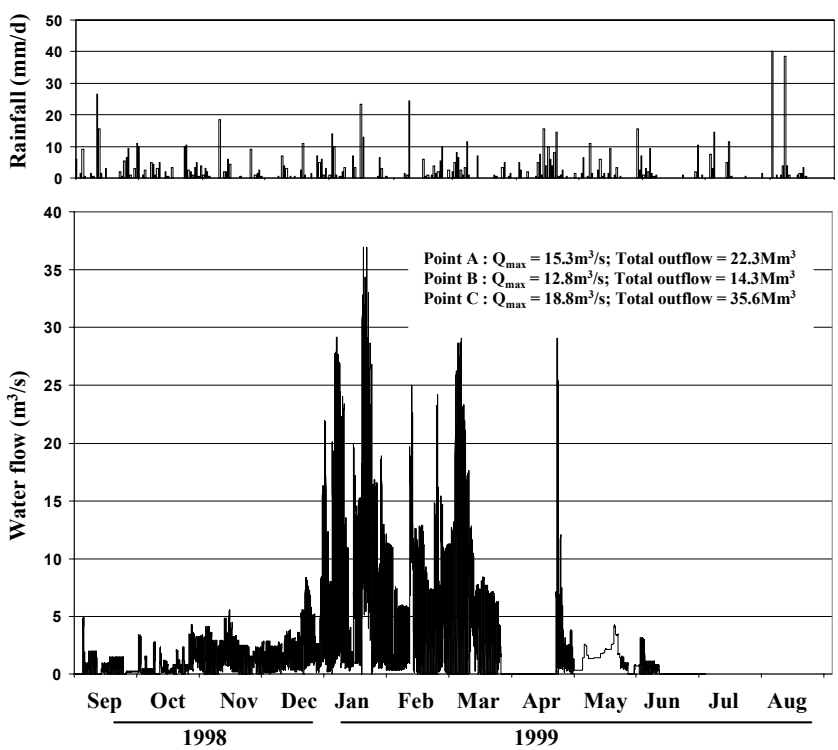

Fig. 2. Total outflow from the marsh and daily rainfall. 


\section{GEOLOGICAL SETTING}

Organisation of the sediments and the 3D structure of the marsh substratum were determined and used to build a hydrogeological code for modelling purposes by interpolation of information obtained from the 70 boreholes drilled into the study site (Fig. 1). The total thickness of the marsh is very heterogeneous and varies from zero to $30 \mathrm{~m}$ (Fig. 3). Two paleo-canyons cross the marsh from north to south and east to south; they were created by erosion of the Kimmeridgian substratum during the last glaciation period, the maximum of which was around 12,000 B.P. and corresponded to a sea level about $120 \mathrm{~m}$ lower than today (Decker et al., 2001). During the subsequent Flandrian transgression, dominantly silty-clayey sediments were deposited progressively up to +3 m.a.s.l., which was the maximum level reached by the sea during this period. This explains why the topography of the marsh is as flat as it is today and why its elevation is around $3 \mathrm{~m}$.

\section{HYDRAULIC HEADS AND GROUNDWATER CIRCULATION}

Using the potentiometric values measured in each piezometer on the marsh, complemented by similar data from agricultural wells in and around the marsh, a first piezometric map of the marsh was drawn up (Fig. 4). Differences in hydraulic head throughout the marsh are only about $1.50 \mathrm{~m}$ to $2 \mathrm{~m}$ but, at the scale of the marsh, the heads present two main outlets in the eastern and western parts of the marsh. This groundwater pattern also occurs at high water level in the marsh. In both the eastern and western part of the marsh, groundwater showed concentric flow lines that are consistent with the geomorphological structure of the marsh and its Kimmeridgian outcrops.

In the underlying Kimmeridgian aquifer, the groundwater flows from the outcrops to the centre of the marsh; the main outlet is also radial and is probably due to a discharge of groundwater into the marsh.

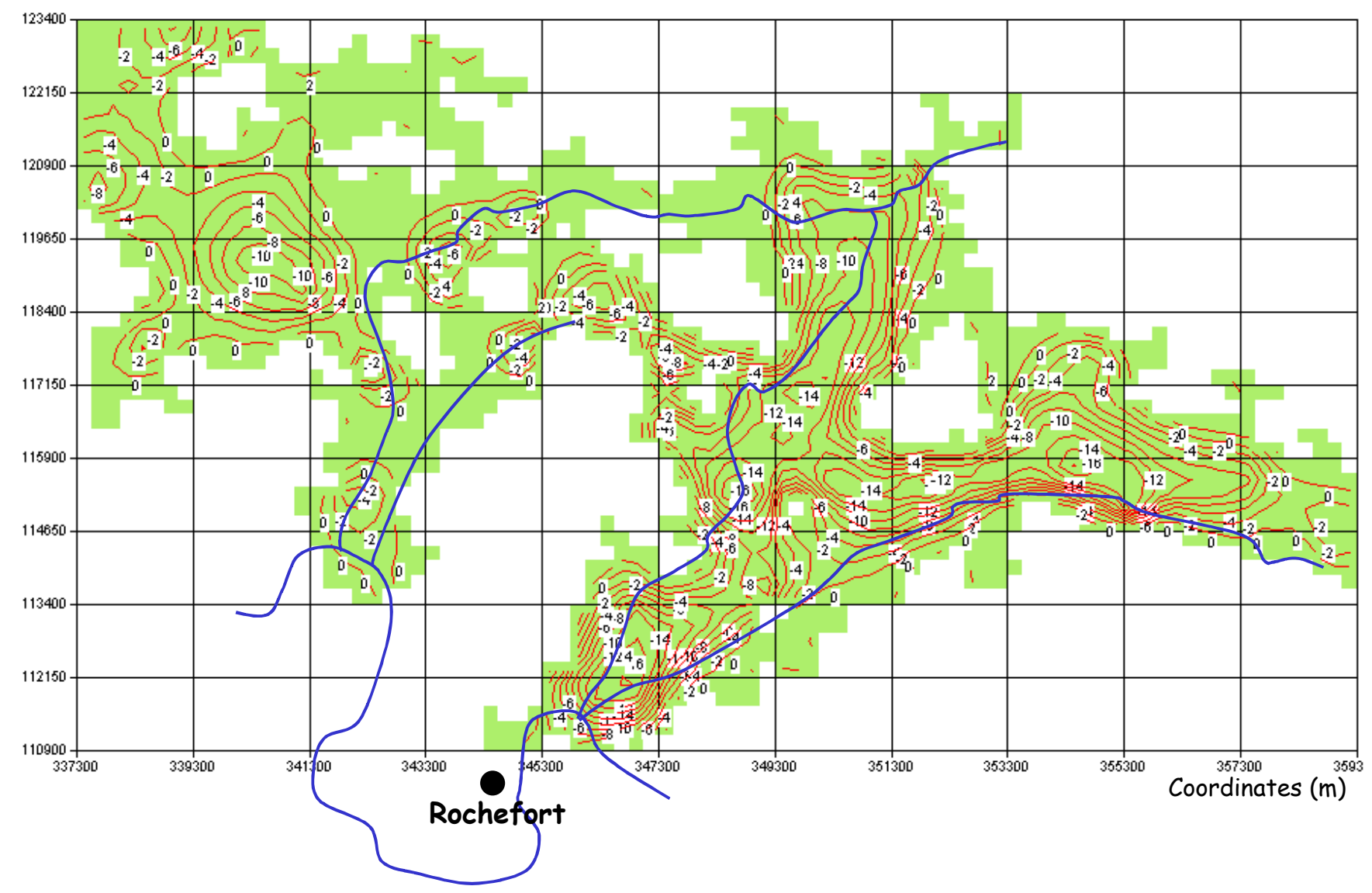

Fig. 3. View of Rochefort Marsh and altitude of the Kimmeridgian substratum (m.a.s.l.) 


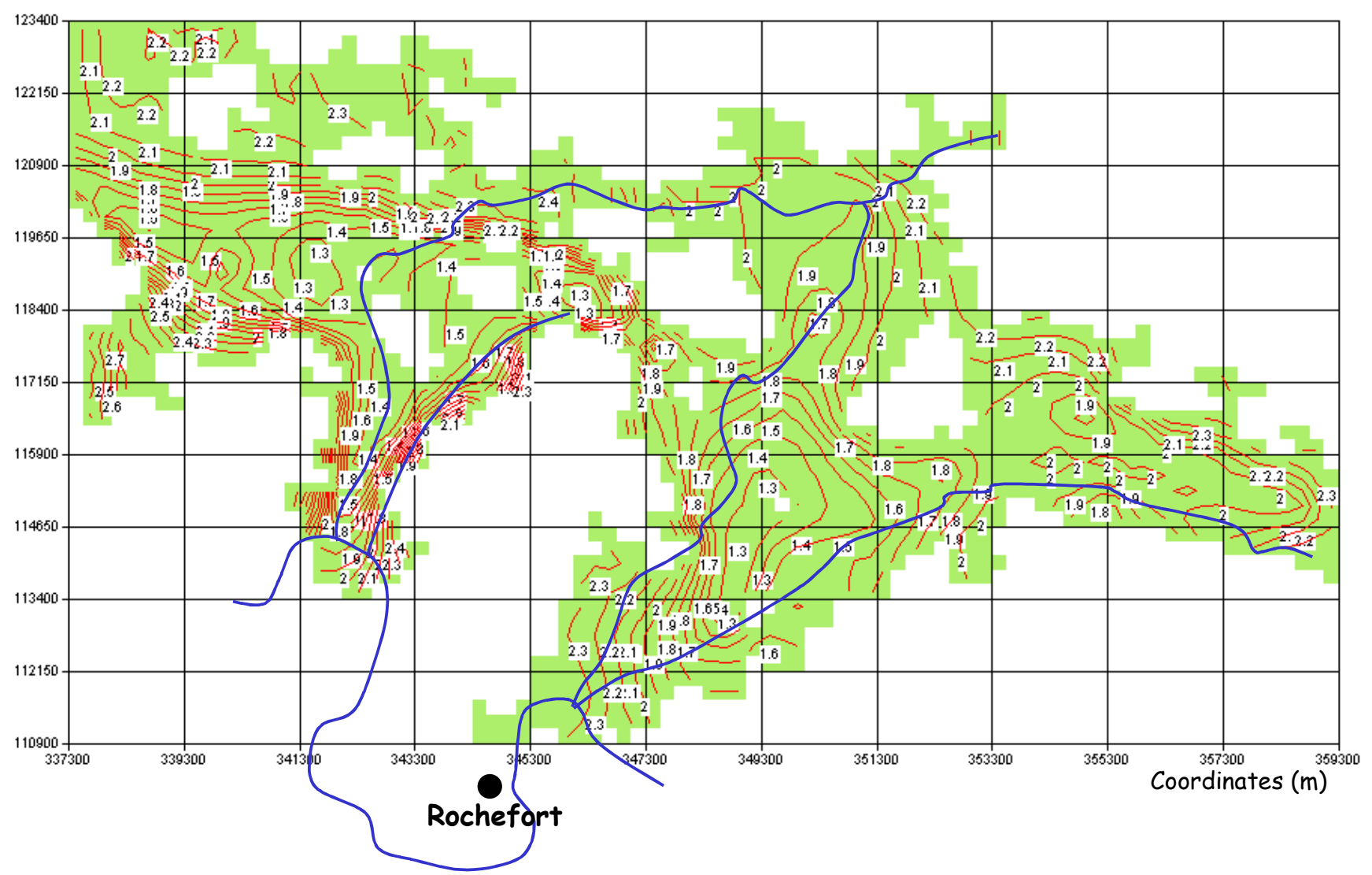

Fig. 4. Measured hydraulic heads in the Marsh (September 1998).

\section{WATER TABLE FLUCTUATION - VERTICAL}

\section{HYDRAULIC GRADIENT}

At the scale of Rochefort Marsh, water table fluctuations and vertical hydraulic gradients between the marsh and its underlying aquifer fall into two groups. Points $\mathrm{E}$ and $\mathrm{F}$ (Fig. 1) are representative of these two groups and water levels are shown in Fig. 5 for the longest recording period, i.e. $1998-2001$.

Firstly, fluctuations in the two connected hydraulic systems (marsh and Kimmeridgian aquifer) are very similar, with high water in winter and low water in summer. Regional climate governs the variations in hydraulic-head for the marsh as a whole. The amplitude of such fluctuations lies between 0.5 and $1 \mathrm{~m}$.

Secondly, a difference was detected in the vertical hydraulic head between the marsh and its underlying aquifer. In some parts of the study site (point $\mathrm{E}$ for example), heads in the Kimmeridgian limestone are consistently higher than in the marsh, so that water flows from the underlying aquifer to the marsh all year round. In other places, such as Point F, the vertical hydraulic heads can be reversed during the year because of a marked increase in the height of the water-
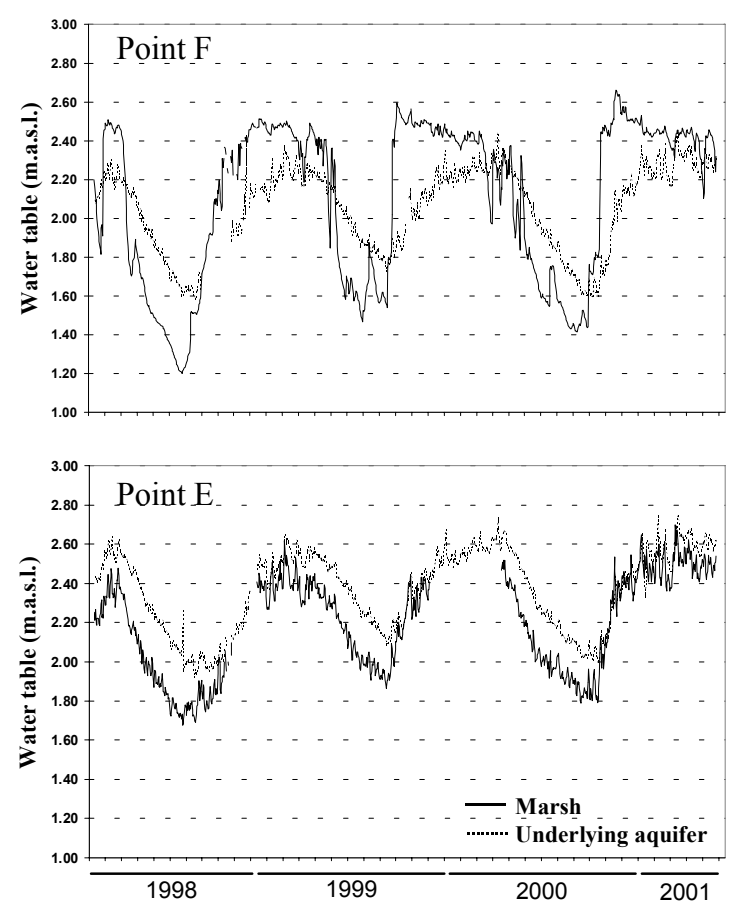

Fig. 5. Water-table fluctuation in the marsh and the underlying aquifer for points $E$ and $F$ (for location, see Fig. 1). 
table in the marsh during the rainy season. In such cases, the water exchange between marsh and underlying aquifer could be upward during summer and downward during winter.

The spatial organisation of the vertical hydraulic gradient (Fig. 6) shows that the downward gradient occurs only: (i) in the central part of the marsh, along a north-south trend; (ii) in the eastern part of the marsh; and (iii) close to the sea. Furthermore, such downward gradients occur only during winter and spring, and they revert to upward flow during summer and early autumn. All other parts of the marsh show upward flow throughout the year.

These observations lead to the conclusion that groundwater contributes to the hydrological functioning of the marsh. In some places, water discharges from the Kimmeridgian aquifer all the year long, while in other places it flows alternatively from marsh to the underlying aquifer or from aquifer to marsh. There was no obvious relationship between land use and upward or downward hydraulic gradients other than the fact that all ditches are still managed empirically by different associations of farmers with the help of a few sluices. Higher water levels in the ditches and canals of some parts of the marsh could directly affect the groundwater level in the marsh and could generate downward flow. However, the volume of water exchanged between the marsh and its underlying aquifer is linked not only to the vertical hydraulic gradient but also to the vertical hydraulic conductivity of the geological structure and to the duration of this gradient.

\section{HYDROLOGICAL MODELLING}

This modelling was done with the 3D finite-difference hydrogeological MARTHE code (Modelisation d'Aquifere par un maillage Rectangulaire en régime Transitoire pour le calcul Hydrodynamique des Ecoulements), developed by Bureau de Recherches Géologiques et Minières (Thiery, 1990; 1993).

MARTHE processes three-dimensional flow by solving the discretised form of Darcy's equation (1856) in a saturated environment or Richards' equation (1931) in an unsaturated environment. The hydrodynamic calculations are carried out using the finite-difference method with an implicit scheme - here the matrical resolution method through conjugated gradients with Choleski pre-conditioning was used. Convergence of the calculations is checked using criteria such as difference in hydraulic head between two successive iterations, residual error flow, etc. This software also has modules for the coupling of a drainage network, for masstransport simulation and for processing the effects of density and temperature in the aquifer.

The two layers considered were the marsh and the Kimmeridgian aquifer. Cells were $250 \mathrm{~m} \times 250 \mathrm{~m}$ (Fig. 7). Based on the geological study, marsh thickness was entered

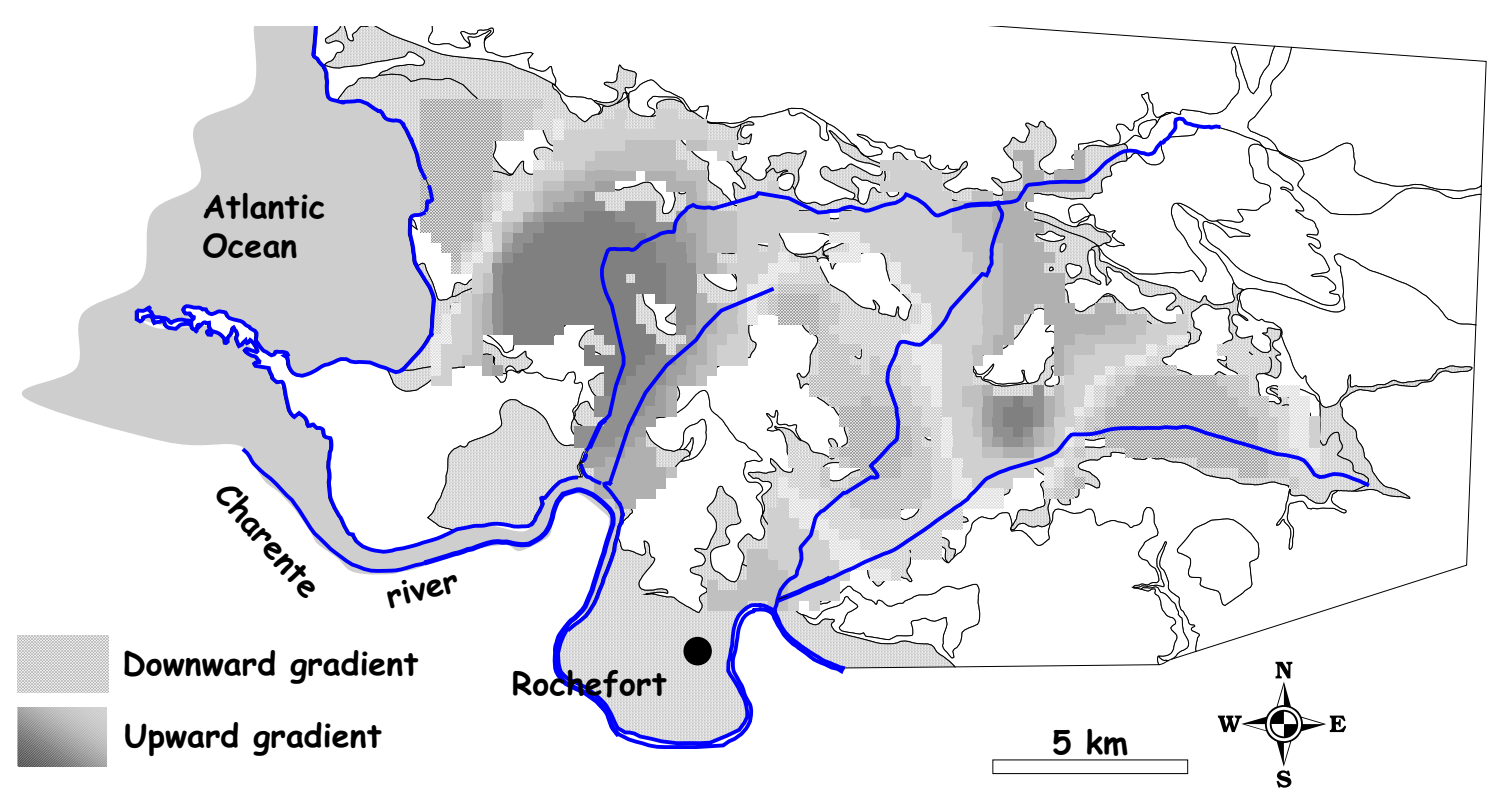

Fig. 6. Vertical hydraulic gradients between Rochefort Marsh and the underlying aquifer (values measured in December 1998). 

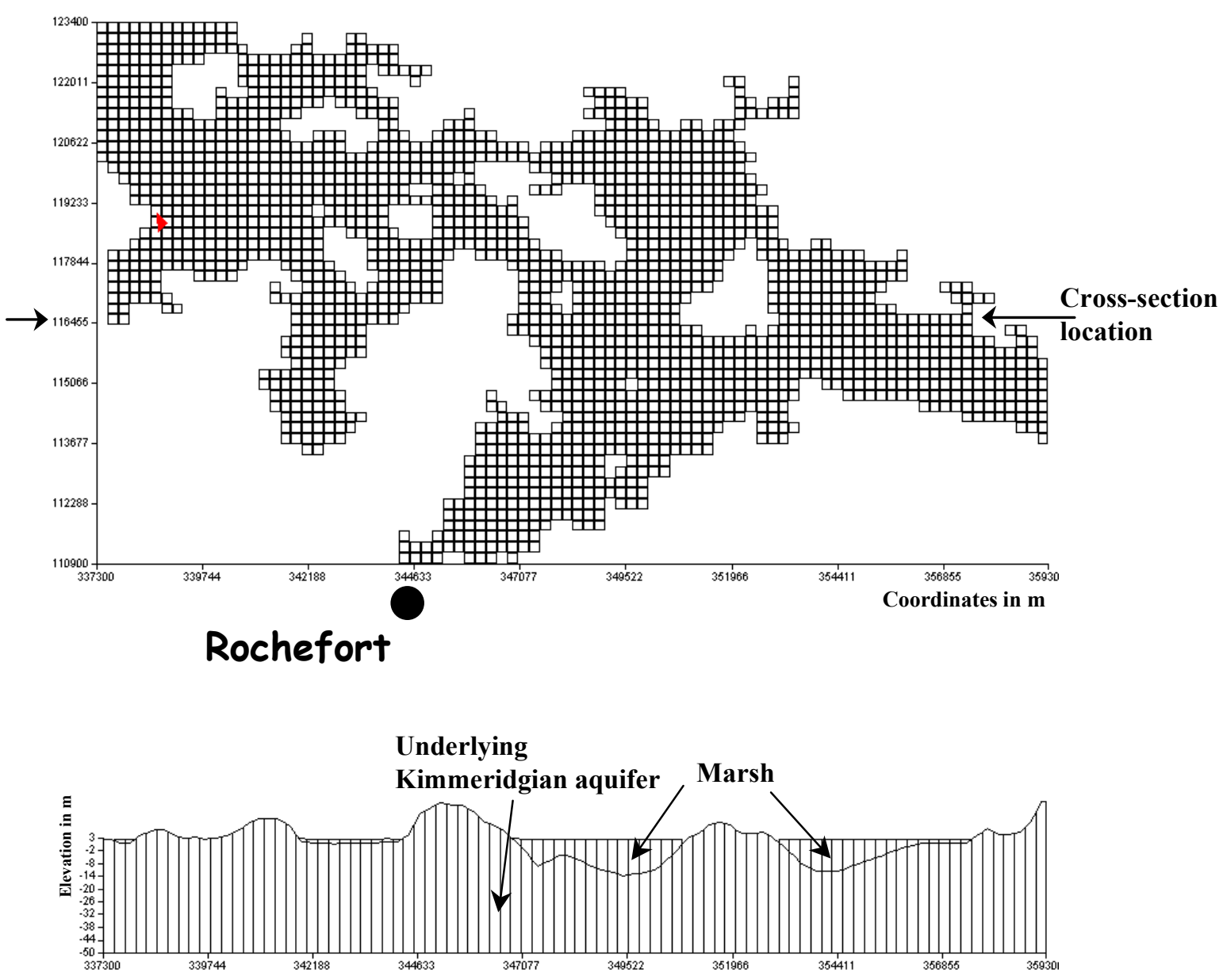

Fig. 7. Model mesh and cross section.

in the modelling for each cell. Wells drilled in the marsh down to the Kimmeridgian aquifer showed that this hydrological system is unproductive below 40 to $50 \mathrm{~m}$ depth, which allowed fixing the aquifer substratum of this model at $-50 \mathrm{~m}$ a.s.1. Boundary conditions of the model (Kimmeridgian limits) were nil flux, justified by the fact that they correspond to a potentiometric crest in the Kimmeridgian aquifer.

Hydraulic conductivities of both marsh and Kimmeridgian aquifer were provided by pumping and slug tests in all piezometers of the study area. Both long time/ constant flow and short time/ varying flow pumping tests were carried out and interpreted with the Theis solution (1935). Slug tests were also conducted in the marsh aquifer and were interpreted using the Hvorslev solution (1951). Measured hydraulic conductivity values are $10^{-9}$ to $10^{-6} \mathrm{~m} \mathrm{~s}^{-1}$ in the marsh and $10^{-8}$ to $5.10^{-5} \mathrm{~m} \mathrm{~s}^{-1}$ in the Kimmeridgian aquifer. The effective porosity of both hydrological systems is between 3 and $13 \%$. Even if the hydraulic conductivity of the marsh were low compared to that in the Kimmeridgian aquifer, it is not the case everywhere and the hydraulic systems are highly heterogeneous.

The first step of the modelling consisted of an inverse steady-state run to spatialise the hydraulic conductivity. After that, the model was run under transient conditions with monthly time steps from September 1998 to August 1999 , to simulate water flow in the marsh and the underlying aquifer. Climatic and agronomic data, such as rainfall, potential evapotranspiration and maximum available moisture, were used to estimate monthly infiltration both in the marsh and on the Kimmeridgian outcrops; these infiltration data were then assigned to each model cell as a function of land use.

Figure 8 compares measured and simulated heads in the marsh and its underlying aquifer for two piezometers $\left(n^{\circ} 2\right.$ and 13, see Fig.1). Modelling in both the marsh and the Kimmeridgian aquifer, where flows are radial and concentrically directed, generated the two central outlets. Comparison between measured and simulated hydraulic heads showed differences of up to $30 \mathrm{~cm}$ across all the 


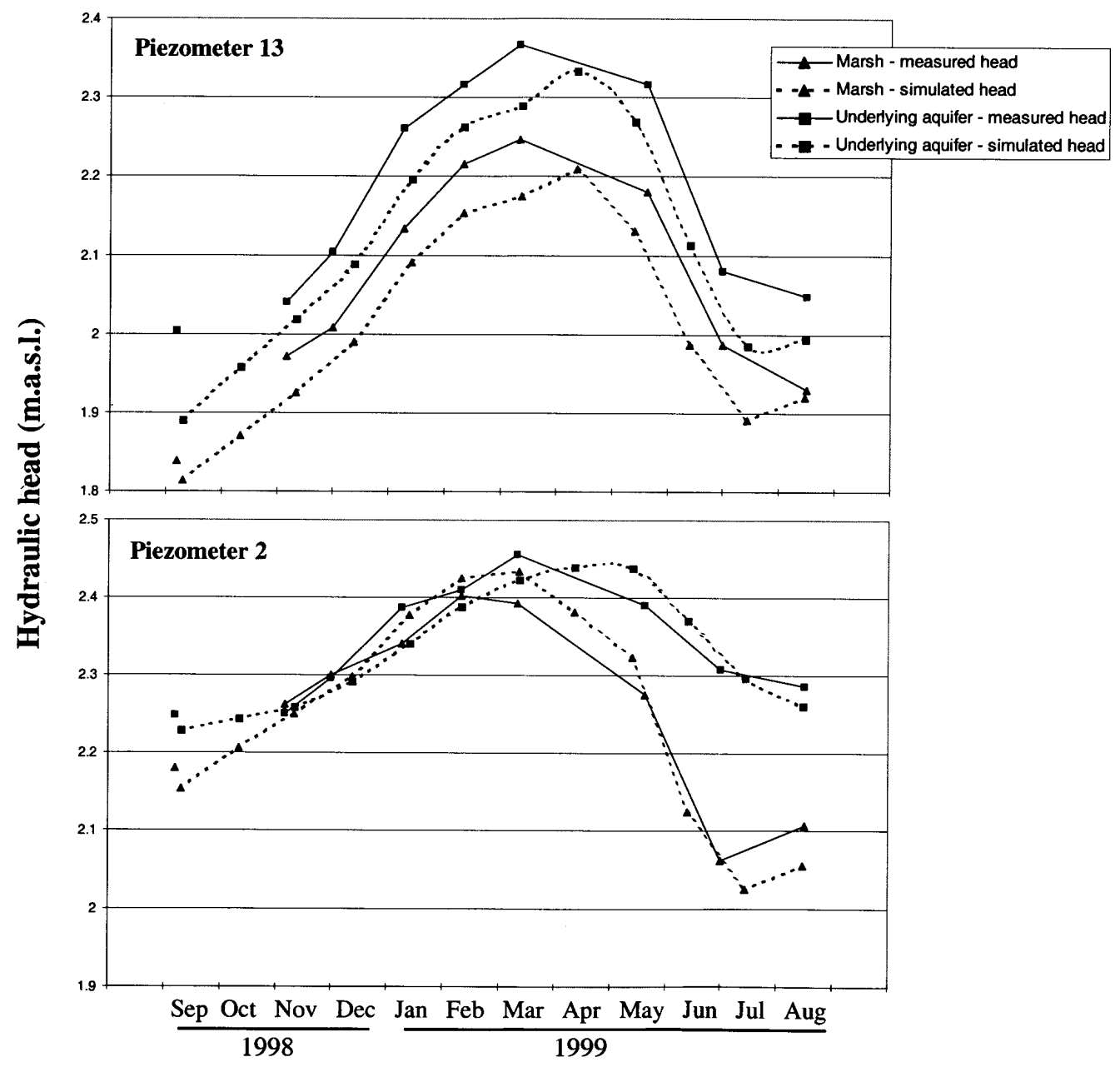

Fig. 8. Comparison between simulated and measured heads in the Marsh and the underlying aquifer.

piezometers in the marsh and during the entire period of the simulation, which indicates that the model can reproduce the hydrological functioning of both the marsh and the underlying aquifer correctly. Small differences in vertical hydraulic heads were simulated and led to water exchanges between the two hydrological systems.

\section{QUANTIFICATION OF WATER FLOW BETWEEN THE \\ WETLAND AND ITS UNDERLYING AQUIFER}

Water discharge from the Kimmeridgian aquifer to the marsh varies in space and time, and could be quantified by modelling (Fig. 9). During the period of September 1998 to August 1999, the cumulative volume of water discharged into the marsh was $770,000 \mathrm{~m}^{3}$. Monthly water flux varied from $37,000 \mathrm{~m}^{3}$ in August to $83,000 \mathrm{~m}^{3}$ in May, and was influenced by rainfall and water uptake by plants.

The volume of water flowing from the marsh to the Kimmeridgian was smaller and represented a total of
$150,000 \mathrm{~m}^{3}$ over the simulated period, varying from $4,800 \mathrm{~m}^{3}$ in May to $22,000 \mathrm{~m}^{3}$ in September.

However, flow from the Kimmeridgian aquifer to the marsh was heterogeneous throughout the marsh. Figure 10 shows the simulated discharge for June 1999, with flux varying by over four orders of magnitude in the marsh and the higher fluxes being located preferentially along the borders. This implies that $70 \%$ of the annual groundwater discharge took place over only $7 \%$ of the surface of the marsh. The volume of water discharged from the underlying aquifer into the marsh is, thus, dependent on the geomorphological configuration of this wetland as well as on the water demand for agricultural purposes.

\section{Conclusions}

An integrated approach to the coastal marsh helps understanding of the hydrological relations that can exist between a wetland and its surroundings. The 3-D geological 


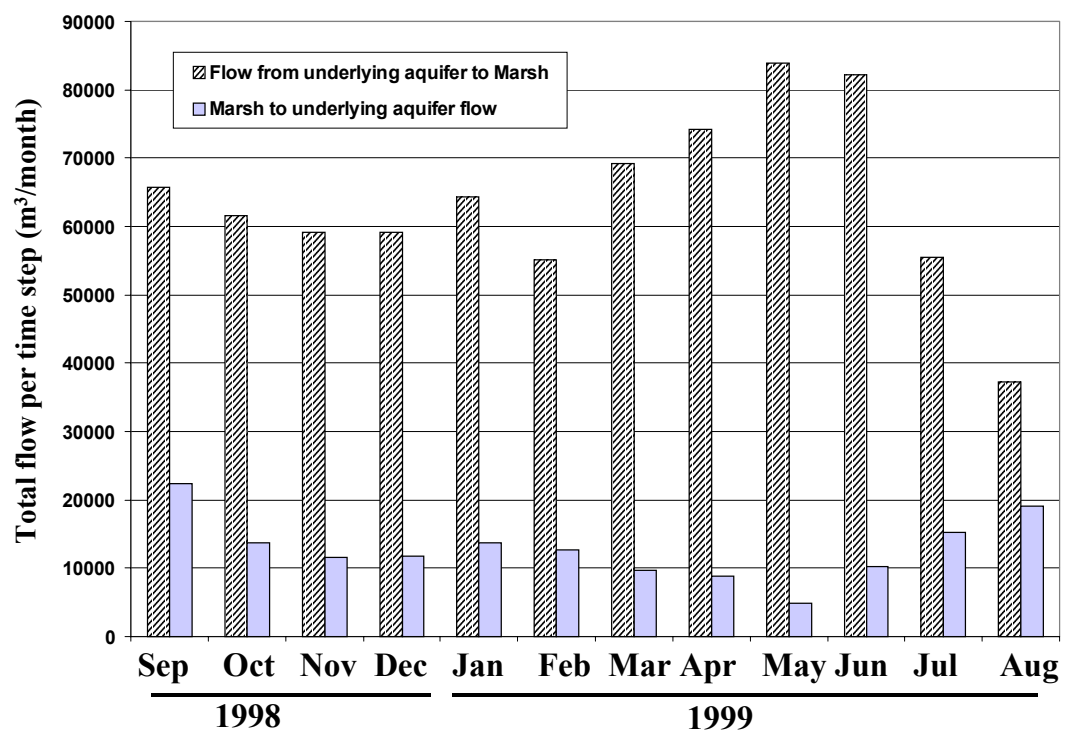

Fig. 9. Water exchange between Rochefort Marsh and the underlying aquifer during the simulated period (September 1998-August 1999).

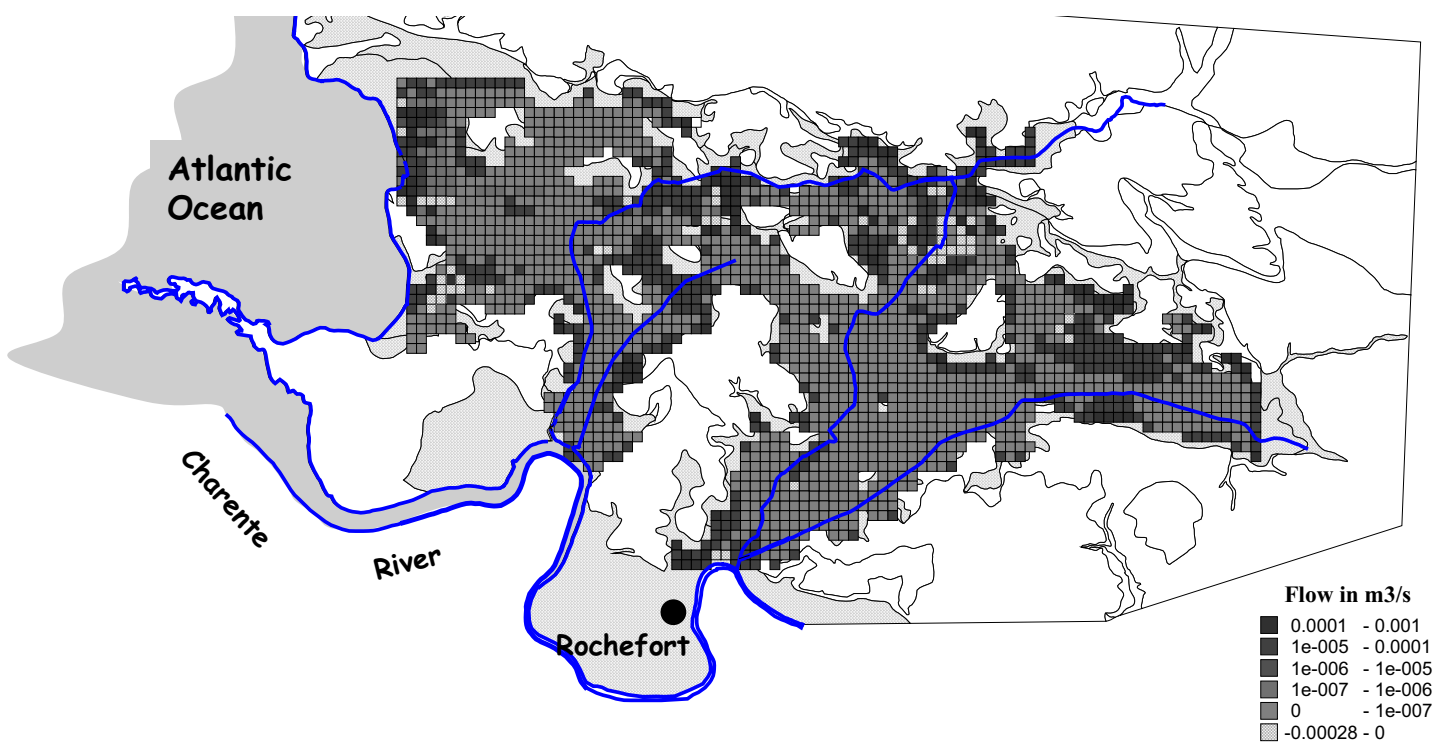

Fig. 10. Simulated water flow from the underlying aquifer to the Marsh (example for June 1999).

structure of the sediment filling the marsh is complex and was inherited from the last glaciation and transgression episode. A coastal basin, formed by the erosion of Kimmeridgian limestone during the last sea-level regression was filled during the Flandrian transgression. The thickness of these Quaternary sediments varies from 0 to about $30 \mathrm{~m}$ throughout the marsh.
Measurement of the hydraulic heads in both the marsh and the underlying Kimmeridgian limestone showed that groundwater flows concentrically towards two central outlets. At the scale of the study site $\left(150 \mathrm{~km}^{2}\right)$, heads are governed seasonally by climatic conditions both in the wetland and in the Kimmeridgian.

Finally, it has been shown that this wetland is potentially 
fed by groundwater, especially along the marsh borders. However, a first modelling approach quantified that only $770,000 \mathrm{~m}^{3}$ of groundwater discharged into the wetland between September 1998 and August 1999. This volume of water represents only 1 to $2 \%$ of the input from precipitation, but could be quite important, i.e. $20 \%$, compared to the $4 \mathrm{Mm}^{3}$ of freshwater pumped from the Charente River into the marsh each year. Such hydrological relations between the wetland and its surroundings should be taken into account in any management system for both environment and agriculture in the marsh.

\section{Acknowledgements}

This study was supported by the BRGM Research Division, the Conseil Général de Charente-Maritime, the Centre d'Etudes Techniques de l'Equipement de l'Ouest, the Agence de l'Eau Adour-Garonne, and the European Commission.

\section{References}

Bendjoudi, H., Weng, P., Guérin, R. and Pastre, J.-F., 2002. Riparian wetlands of the middle reach of the Seine River (France): historical development, investigation and present hydrologic functioning. A case study. J Hydrol., 263, 131-155.

Brinson, M.M., 1993. A hydrogeomorphic classification for wetlands. Report WRP-DE-4, U.S. Army Corps of Engineers, Vicksburg.

Carter, V., 1986. An overview of the hydrologic concerns related to wetlands in the United States. Can. J. Bot., 64, 364-374.

Cey, E.E., Rudolph, D.L., Parkin, G.W. and Aravena, R., 1998. Quantifying groundwater discharge to a small perennial stream in southern Ontario, Can. J. Hydrol., 210, 21-37.

Darcy, H. de, 1856. Les fontaines publiques de la ville de Dijon. Dalmont, Paris.

Decker, I., Le Strat, P., Karnay, G., Bourgine, B. and Vairon, J., 2001. Géométries et dynamique de remblayage de l'incision holocène dans le marais de Rochefort: modélisation géologique. Report RP-51007-FR, BRGM.

Devito, K.J. and Dillon, P.J., 1993. The influence of hydrologic condition and peat oxia on the phosphorus and nitrogen dynamics of a conifer swamp. Water Resour. Res., 29, 26752685.

Fleury, P., 2001. Analyse et modélisation du fonctionnement hydrologique du marais de Rochefort. M. Sc. Thesis. Université de Paris. 48 pp.

Fustec, E. and Lefeuvre, J.C., 2000. Fonctions et valeurs des zones humides. Dunod, Paris, $426 \mathrm{pp}$.

Gasca-Tucker, D.L. and Acreman, M.A., 2000. Modelling ditch water levels on the Pevensey levels wetland, a lowland wet grassland wetland in East Sussex, UK. Phys. Chem. Earth, 25, 593-597.
Gilbert, S., 1998. Evaluation des échanges entre les eaux de surface et les eaux souterraines dans le marais de Rochefort. MSc. Thesis. Université des Sciences et Technologies de Lille $1.54 \mathrm{pp}$.

Gilman, K., 1994. Hydrology and wetland conservation. Wiley, Chichester, UK. 101 pp.

Giraud, F. et al., 2000. Etude hydrologique et hydrogéologique du marais de Rochefort (Charente-Maritime). Report RP-50247FR, BRGM.

Hayashi, M. and Rosenberry, D.O., 2002. Effects of ground water exchange on the hydrology and ecology of surface water. Ground Water, 40, 309-316.

Hill, A.R., 1990. Ground Water flow paths in relation to nitrogen chemistry in the near-stream zone. Hydrobiologia, 206, 39-52.

Hunt, R.J., Krabbenhoft, D.P. and Anderson, M.P., 1996. Groundwater inflow measurements in wetland systems. Water Resour. Res., 32, 495-507.

Hunt, R.J., Krabbenhoft, D.P. and Anderson, M.P., 1997. Assessing hydrogeochemical heterogeneity in natural and constructed wetlands. Biogeochemistry, 34, 271-293.

Hvorslev, J.M., 1951. Time lag and soil permeability in groundwater measurements. U.S. Army Corps of Engineers, Vicksburg, Missouri.

LaBaugh, J.W., 1986. Wetland ecosystem studies from a hydrologic perspective. Water Resour. Bull., 22, 1-10.

Lencastre, A., 1983. Manuel d'hydraulique générale. Eyrolles, Paris, 409 pp.

Mitsch, W.J. and Gosselink, J.G., 1993. Wetlands. VanNostrand Reinhold, New York, 722 pp.

Morrison, M., Bennett, J. and Blamey, R., 1999. Valuing improved wetland quality using choice modeling. Water Resour. Res., 35 , $2805-2814$.

Richards, L.A., 1931. Capillary conduction of liquids through porous mediums. Physics, 1, 318-333.

$\mathrm{Su}$, M., Stolte, W.J. and van der Kamp, G., 2000. Modelling Canadian prairie wetland hydrology using a semi-distributed streamflow model. Hydrol. Process., 14, 2405-2422.

Tchamen, G.W. and Kahawita, R.A., 1998. Modelling wetting and drying effects over complex topography. Hydrol. Process., 12, 1151-1182.

Theis, C.V., 1935. The relation between the lowering of the piezometric surface and the rate and duration of discharge of a well using groundwater storage. Trans. Amer. Geophys. Un., Ann. Meet., 16, 519-524.

Thiery, D., 1990. Logiciel MARTHE. Modélisation d'Aquifère par un maillage Rectangulaire en régime Transitoire pour un calcul Hydrodynamique des Ecoulements - version 4.3. Report R32210 EAU 4S 90, BRGM, Orléans.

Thiery, D., 1993. Résolution matricielle et nouvelles géométries dans le logiciel MARTHE. Report 4S EAU R 37762, BRGM, Orléans.

Weng, P., 2000. Fonctionnement hydrologique d'une zone humide alluviale, relations avec l'aquifère sous-jacent et les rivières. Exemple de la Seine moyenne. PhD Thesis, Université de Paris. $202 \mathrm{pp}$.

Winter, T.C., 1999. Relation of streams, lakes, and wetlands to groundwater flow systems. Hydrogeol. J., 7, 28-45. 